\title{
Root distribution according to phenology in plantain cultivars (Musa AAB), Ecuador
}

\author{
Leonardo Enrique Avellán-Vásquez ${ }^{1}$, Sandra Tatiana Estévez-Chica², Diego Alfonso Vaca-Sotelo ${ }^{3}$, \\ Myriam Elizabeth Zambrano-Mendoza ${ }^{4}$, Tito Alexander Cedeño-Loor ${ }^{5}$, Adriana Beatriz Sánchez-Urdaneta ${ }^{6}$
}

Abstract - Plantain is the fourth most important crop in the world, considered as a basic and export product in Ecuador. The root distribution of three plantain cultivars (Musa AAB) grown in Ecuador was evaluated at the "Río Suma" Experimental Farm, "Laica Eloy Alfaro de Manabí" University, $0^{\circ} 15^{\prime} \mathrm{S}, 79^{\circ} 26^{\prime}$ W. Plantain cultivars were 'Barraganete', 'Curare Enano' and 'Dominico Hartón', and root distribution was determined according to the phenology of plants $(10,20,30,40$ leaves (inflorescence) and harvest), seeded at $2.5 \mathrm{~m} \times 1.8 \mathrm{~m}$. In a completely randomized block design with five replicates, five plants $\cdot$ cultivar $^{-1}$ were selected for each evaluation. Root distribution was carried out in soil profiles between rows. The greatest root distribution occurred $20 \mathrm{~cm}$ laterally, up to 40 $\mathrm{cm}$ in depth. Longitudinally, 'Curare Enano' roots occurred up to $60 \mathrm{~cm}$, 'Dominico Hartón' (50 $\mathrm{cm})$ and 'Barraganete' $(40 \mathrm{~cm})$; at $40 \mathrm{~cm}$ in depth 'Barraganete' and 'Curare Enano' had roots up to $30 \mathrm{~cm}$ in length and 'Dominico Hartón' up to $50 \mathrm{~cm}$. The root distribution of the three cultivars can establish agronomic management criteria to determine plant density, fertilization and irrigation. Index terms: Musa sp., root development, phenology, depth, number of roots.

\section{Distribuição radicular de acordo com a fenologia em cultivares de plátano (Musa AAB), Equador}

\section{Corresponding author: usanchez.luz@gmail.com}

Received: August 30, 2020 Accepted: January 13, 2021

Copyright: All the contents of this journal, except where otherwise noted, is licensed under a Creative Commons Attribution License.

(cc) $\mathbf{E Y}$

\begin{abstract}
Resumo - Plátano é a quarta cultura mais importante do mundo, considerada um produto básico e de exportação do Equador. A distribuição radicular de três cultivares de plátano (Musa AAB) cultivadas no Equador foi avaliada na Fazenda Experimental "Río Suma", Universidade "Laica Eloy Alfaro de Manabí', $0^{\circ} 15$ 'S, 79²6' W. As cultivares de plátano foram 'Barraganete', 'Curare Enano' e 'Dominico Hartón', e a distribuição radicular foi determinada de acordo com a fenologia das plantas $(10 ; 20 ; 30$ e 40 folhas (inflorescência) e colheita), semeadas a 2,5 m x 1,8 m. Em um delineamento de blocos inteiramente casualizados, com cinco repetições, cinco plantas $\cdot$ cultivar $^{-1}$ foram selecionadas para cada avaliação. A distribuição radicular foi realizada em perfis de solo entre as linhas. A maior distribuição radicular ocorreu de $20 \mathrm{~cm}$ lateralmente, até $40 \mathrm{~cm}$ de profundidade. Longitudinalmente, as raízes de 'Curare Enano' ocorreram até $60 \mathrm{~cm}$, 'Dominico Hartón', $50 \mathrm{~cm}$ e 'Barraganete', $40 \mathrm{~cm}$; a $40 \mathrm{~cm}$ de profundidade, 'Barraganete' e 'Curare Enano' tinham raízes de até $30 \mathrm{~cm}$ de comprimento e 'Dominico Hartón' de até $50 \mathrm{~cm}$. A distribuição radicular das três cultivares pode estabelecer critérios de manejo agronômico para determinar a densidade de plantas, a fertilização e a irrigação.
\end{abstract}

Termos para indexação: Musa sp., desenvolvimento radicular, fenologia, profundidade, número de raízes.

\footnotetext{
${ }^{1}$ Agricultural Engineer, MSc. Professor-Researcher in Agricultural Engineering, "Laica Eloy Alfaro de Manabí” University, El Carmen. Ecuador. Email: leonardo.avellan@uleam.edu.ec (ORCID: 0000-0003-4265-8049)

${ }^{2}$ Graduate. Professor. “Tacio Castillo Díaz” Educational Unit. El Carmen, Ecuador. CP 130401. Email: sandritaestevez@ hotmail.com(ORcid: 0000-0003-2492-3582)

${ }^{3}$ Agronomist, MSc. PhD student in Agricultural Sciences, Faculty of Agronomy, University of Zulia. Maracaibo, Venezuela. Email: diegoalf13@ gmail.com (ORCID: 0000-0002-0799-3928)

${ }^{4}$ Agricultural Engineer, MSc. Professor-Researcher in Agricultural Engineering, "Laica Eloy Alfaro de Manabí" University, El Carmen. Ecuador. Email: miriamzame@hotmail.com (ORCID: 0000-0002-5307-6362)

${ }^{5}$ Economist, MSc. Professor-Researcher in Accounting and Auditing, "Laica Eloy Alfaro de Manabí" University, El Carmen. Ecuador. Email: tito.cedeno@uleam.edu.ec (ORCID: 0000-0001-6583-1233)

${ }^{6}$ Agronomist, PhD. Professor-Researcher, Department of Botany, Faculty of Agronomy, University of Zulia. Maracaibo, Venezuela. Email:

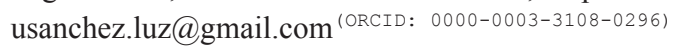




\section{Introduction}

The expected growth of the world population, accompanied by increased demand for proteins of animal origin, leads to a global scenario where the challenge facing the primary food production sector is the increase in crop productivity. Fixen (2010) indicated that it is essential to increase agricultural production by $2.4 \%$ per year, since food requirements will double in the next 30 years, which becomes a challenge from the sustainability point of view.

Furthermore, as agricultural management becomes more efficient, vertical production growth should be pursued (increasing production and productivity), since there is increasing competition for land between urban and industrial sectors and the food production sector.

One of the aspects that should be considered to increase crop production is the intensive soil management, which that involves every element that depend on it, including fertilization, allowing improving yields continuously; therefore, improvements in the management of the quantity and availability of soil nutrients become increasingly important. Likewise, it is necessary to know the distribution patterns of roots, since they play a significant role in the competition for space, water absorption and nutrients (DÍAZ-ZORITA; GRASSO, 2017).

The low productivity levels and the increase in surface area indicate that plantain and banana activity has been maintained based on increase in cultivated area, rather than increase in productivity. So, of the total planted area, around $33 \%$ receive fertilization and only $34 \%$ control pests and diseases, and more than $60 \%$ of the national area does not have access to technology (NATIONAL INSTITUTE OF STATISTICS AND CENSUSES (INEC), 2017).

Due to the search for efficiency, it is to know the root systems of plants, which are designed to meet different plant requirements in terms of anchorage in the substrate, acquisition and transport of soil resources (water, essential minerals, among others), and their storage. The mineral nutrition of plants is essentially under genetic control, since root distribution (architecture) determines the soil volume available for the extraction of water and minerals; also in addition, the functioning of transporters in the membranes of radicle cells represents a physiological process highly regulated by the activity of genes and influenced by multiple biotic and abiotic factors (DUQUE; VILLORDON, 2019).

Sánchez-Calderón et al. (2013) indicated that the root system distribution is specific to each species and is genetically governed, which establishes high phenotypic plasticity, particularly in response to environmental stress. However, Ogura et al. (2019) and Waidmann et al. (2019) pointed out that the radial expansion of the root system depends on the directional growth of primary and secondary roots, where auxins play a central role in aligning the growth of the radical organ towards gravity, thus regulating the responses of roots for their local adaptation.

Due to the inability of plants to move around, they require roots able to efficiently obtain water and nutrients. Therefore, the root systems of plants are dynamic organizations, which tend to modify their distribution and development rate to establish their general architecture. This plasticity ensures plants to adapt to favorable or unfavorable conditions present in the soil, the product of a series of endogenous development processes and environmental interactions that allow them to guarantee appropriate access to water and soil nutrients (DUQUE; VILLORDON, 2019).

The knowledge of the multiple physiological effects of roots on the stem has resulted in the development of agricultural practices that modify the architectural and physiological behavior of roots. These practices include crops fertilization, root pruning in windbreak systems, forced fruit tree harvest, nursery root pruning, use of growth regulators in the development control of roots and inoculations with symbionts (PAGÈS et al., 2013).

Due to the relevance of roots in the physiological and productive processes of plants, the complexity of factors that affect the root system and the scarcity of studies carried out on roots for production systems, the root distribution of three plantain cultivars (Musa AAB) at different phenological stages was evaluated in El Carmen, Ecuador.

\section{Materials and methods}

The research was carried out at the "Río Suma" Experimental Farm at "Laica Eloy Alfaro de Manabí" University, El Carmen, located in the Canton El Carmen, Province of Manabí, coordinates coordinates $0^{\circ} 15^{\prime} \mathrm{S}$ and $79^{\circ} 26^{\prime} \mathrm{W}$, in humid tropical climate. The agro-ecological characteristics were altitude of 263 m.a.s.l., average temperature of $24{ }^{\circ} \mathrm{C}$, average annual precipitation of $2,806 \mathrm{~mm} \cdot$ year $^{-1}$, evaporation of $1,064 \mathrm{~mm} \cdot$ year $^{-1}$, relative humidity of $86 \%$ and heliophany of 1,026 light hours 'year ${ }^{-1}$ (NATIONAL INSTITUTE OF METEOROLOGY AND HYDROLOGY (INAMHI), 2017). Avellán-Vásquez et al. (2020) indicated that the texture of soils was sandy loam ( $62 \%$ sand, $28 \%$ silt and $10 \%$ clay).

The study evaluated first cycle of 'Barraganete', 'Curare Enano' and 'Dominico Hartón' plantain cultivars (Musa AAB), seeded at distance of $2.5 \mathrm{~m}$ between rows $\mathrm{x} 1.8 \mathrm{~m}$ between plants $\left(4.5 \mathrm{~m}^{2}\right)$, for a total of 2,222 plants $\cdot \mathrm{ha}^{-1}$, corresponding to high-density plants management. 
Guerrero (2010) indicated that plantain has phenological development that comprises three phases: vegetative, floral and fruiting. The vegetative phase, lasting 6 months, includes the formation of main and secondary roots, with the development of pseudostem and offspring. The floral phase corresponds to the presence of inflorescence, being considered the change from the vegetative phase to the reproductive phase, lasting approximately 3 months after 6 months of the vegetative phase. The flower stalk rises from the corm through the pseudostem and is visible at the time of inflorescence emergence (VARGAS-CALVO et al., 2015). The fruiting phase lasts from 2 to 3 months and occurs after the floral phase. Male and female flowers (fingers) are differentiated in this phase and there is a gradual decrease in leaf area, which ends with harvest, and the time from the beginning of flowering to the bunch harvest is 60 to 90 days (ARISTIZÁBAL; JARAMILLO, 2010).

The roots of five plants were evaluated according to the phenology of cultivars, which was related to the number of leaves, as indicated in Table 1; both roots that developed towards the right and left of the plant and totals; in addition to root distribution depth.

Table 1. Phenological stages used for the study of the root distribution of 'Barraganete', 'Curare Enano' and 'Dominico Hartón' (Musa AAB) plantain cultivars cultivated at the "Río Suma" Experimental Farm, "Laica Eloy Alfaro de Manabí" University, El Carmen, Ecuador.

\begin{tabular}{l}
\hline Phenological stages \\
I. From transplantation to emission of leaf 10. \\
II. From the emission of leaf 11 to the emission of leaf 20. \\
III. From the emission of leaf 21 to the emission of leaf 30. \\
IV. From the emission of leaf 31 to the inflorescence emission. \\
V. From flowering to harvest.
\end{tabular}

Plants were at the required age based on foliar emission (leaves 10, 20, 30, 40 (inflorescence) and harvest), under the same conditions of competition for light, water and nutrients with surrounding plants and without apparent presence of diseases.

Once the above was verified, soil cut (soil profile) of up to $60 \mathrm{~cm}$ in length on each side of the plant and the same value in depth was carried out. Subsequently, the outer edges of the square were marked with three-inch nails, which was performed every $10 \mathrm{~cm}$, both in length and depth, delimiting grids with a rope. Once grids were delimited, the number of roots present in each quadrant was counted, to be averaged with five replicates and to make the graphical representation of the root distribution.

A completely randomized experimental block design with factorial treatment arrangement was used, with the following factors: cultivars at three levels ('Barraganete', 'Curare Enano' and 'Dominico Hartón') and phenological stages at five levels (leaves 10, 20, 30 and 40 (inflorescence) and harvest) with five replicates.

For data processing, the GLM procedure of the Statistical Analysis System (SAS ${ }^{\circledR}$ version 15.1, 2020) for Windows was used through the analysis of variance and multiple means tests by Tukey $(\mathrm{P} \leq 95 \%)$ for the means of factors and their interaction through the LSMEANS procedure.

\section{Results and discussion}

Statistical differences $(\mathrm{P}<0.0001)$ were found due to the effect of treatments (cultivars and phenological stages) for variables number of roots to the right (NRR) and total (TNR) and for the interaction cultivars by phenological stages; however, the number of roots developed to the left of the plant (NRL) and the interaction of factors were statistically equal $(\mathrm{P}>0.05)$ (Table 2$)$.

NRR in the 'Barraganete' cultivar presented the highest number, with average of 27.73 roots $\cdot$ plant $^{-1}$, statistically different $(\mathrm{P}<0.007)$ from 'Curare Enano' cultivar (15.97 roots plant $\left.^{-1}\right)$, which was 1.74 times higher. There were no differences between 'Barraganete' and 'Dominico Hartón' cultivars (22.28 roots · plant $\left.{ }^{-1}\right)$ and between 'Dominico Hartón' and 'Curare Enano' cultivars. The same behavior was presented for TNR, where 'Barraganete' cultivar had average of 45.37 roots $\cdot$ plant $^{-1}$, followed by 'Dominico Hartón' cultivar, with 44.85 roots $\cdot$ plant $^{-1}$ and finally 'Curare Enano' cultivar, with 33.17 roots 'plant ${ }^{-1}$. 'Barraganete' and 'Dominico Hartón' cultivars were 1.37 and 1.35 times greater, respectively, than 'Curare Enano' cultivar (Table 2).

The highest number of roots was found in the upper part of the soil profile, $94.01 \%$ of roots of the three plantain cultivars evaluated at the different phenological stages were located in the first $20 \mathrm{~cm}$ in depth, between 30 and $40 \mathrm{~cm}$ in depth presented $5.21 \%$ of roots and between 50 
and $60 \mathrm{~cm}$ in depth, $0.78 \%$ of roots (Figures 1, 2, 3 and 4 ). In this sense, only 'Dominico Hartón' cultivar presented roots found between 50 and $60 \mathrm{~cm}$ in depth, $51.20 \%$ of total roots appeared to the right and $48.80 \%$ to the left of the plant.

Table 2. Number of roots to the right (NRR), to the left (NRL) and total (TNR) of the plant, in 'Barraganete', 'Curare Enano' and 'Dominico Hartón' (Musa AAB) plantain cultivars cultivated at the "Río Suma” Experimental Farm, "Laica Eloy Alfaro de Manabí” University, El Carmen, Ecuador.

\begin{tabular}{lccc}
\hline \multicolumn{1}{c}{ Treatments } & \multicolumn{3}{c}{ Variables evaluated } \\
\hline \multicolumn{1}{c}{ Cultivars } & $\begin{array}{c}\text { Roots to the right } \\
\text { (NRR) }\end{array}$ & $\begin{array}{c}\text { Roots to the left } \\
\text { (NRL) }\end{array}$ & $\begin{array}{c}\text { Total roots } \\
\text { (TNR) }\end{array}$ \\
\hline 'Barraganete' & $27.73 \mathrm{a}$ & $20.30 \mathrm{a}$ & $45.37 \mathrm{a}$ \\
'Curare Enano' & $15.97 \mathrm{~b}$ & $17.13 \mathrm{a}$ & $33.17 \mathrm{~b}$ \\
'Dominico Hartón' & $22.28 \mathrm{ab}$ & $22.73 \mathrm{a}$ & $44.85 \mathrm{a}$ \\
Phenological stages & & & \\
10 leaves & $10.00 \mathrm{~b}$ & $17.22 \mathrm{a}$ & $27.22 \mathrm{~b}$ \\
20 leaves & $20.22 \mathrm{~b}$ & $20.62 \mathrm{a}$ & $40.84 \mathrm{ab}$ \\
30 leaves & $23.97 \mathrm{ab}$ & $20.54 \mathrm{a}$ & $44.24 \mathrm{ab}$ \\
40 leaves (inflorescences) & $31.78 \mathrm{a}$ & $27.56 \mathrm{a}$ & $58.22 \mathrm{a}$ \\
Harvest & $20.67 \mathrm{ab}$ & $14.33 \mathrm{a}$ & $35.11 \mathrm{~b}$ \\
\hline
\end{tabular}

Averages followed by the same letter in column do not differ statistically from each other by the Tukey's multiple mean test, at $5 \%$ probability level.

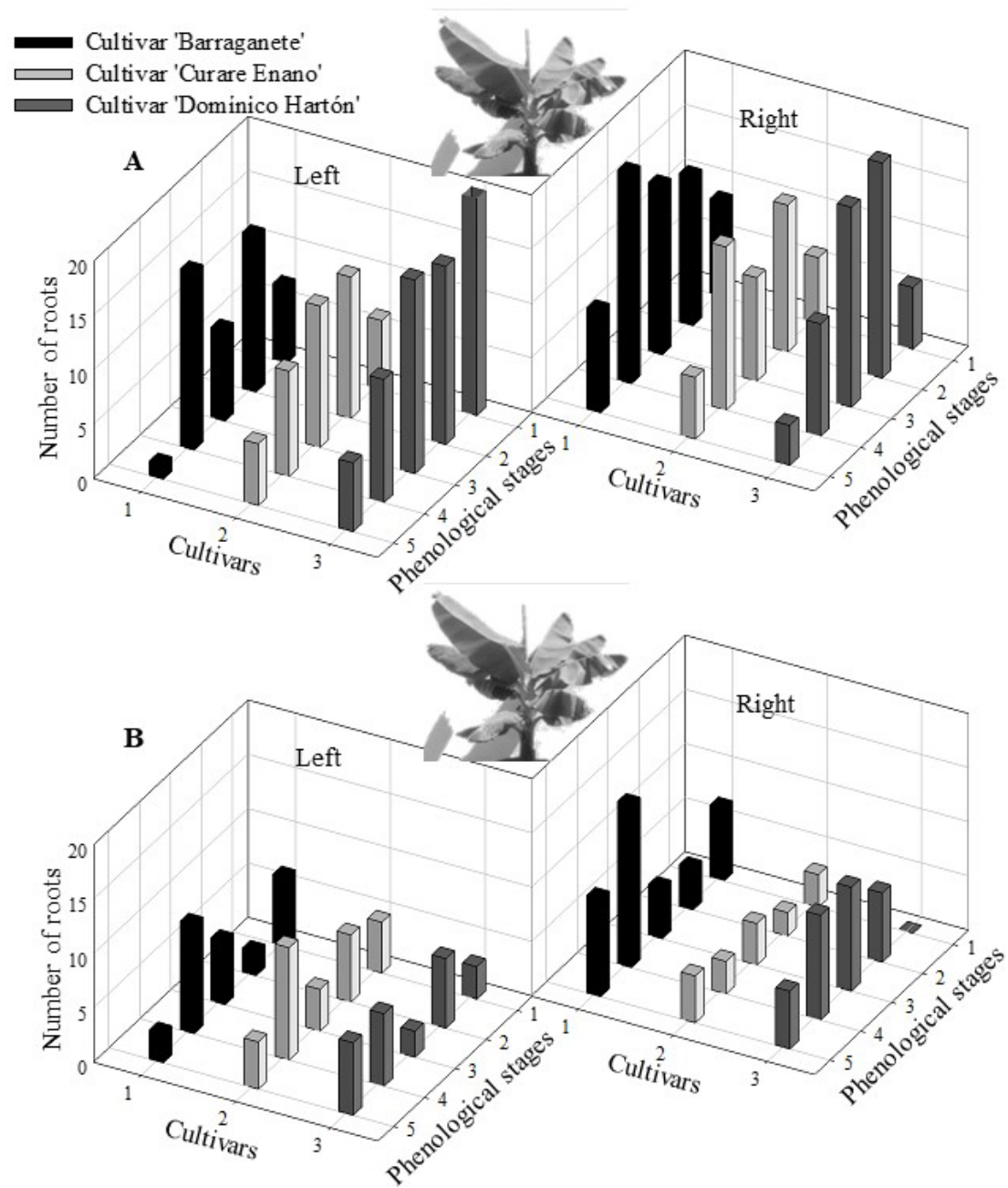

Figure 1. Map of the average root distribution of plantain cultivars, 1) 'Barraganete' (black bar), 2) 'Curare Enano' (light gray bar) and, 3) 'Dominico Hartón' (dark gray bar). A) $10 \mathrm{~cm}$ in length to the right and left, B) $20 \mathrm{~cm}$ in length to the right and left, and up to $40 \mathrm{~cm}$ in depth in plants analyzed at the "Río Suma" Experimental Farm, "Laica Eloy Alfaro de Manabí" University, El Carmen, Ecuador. 


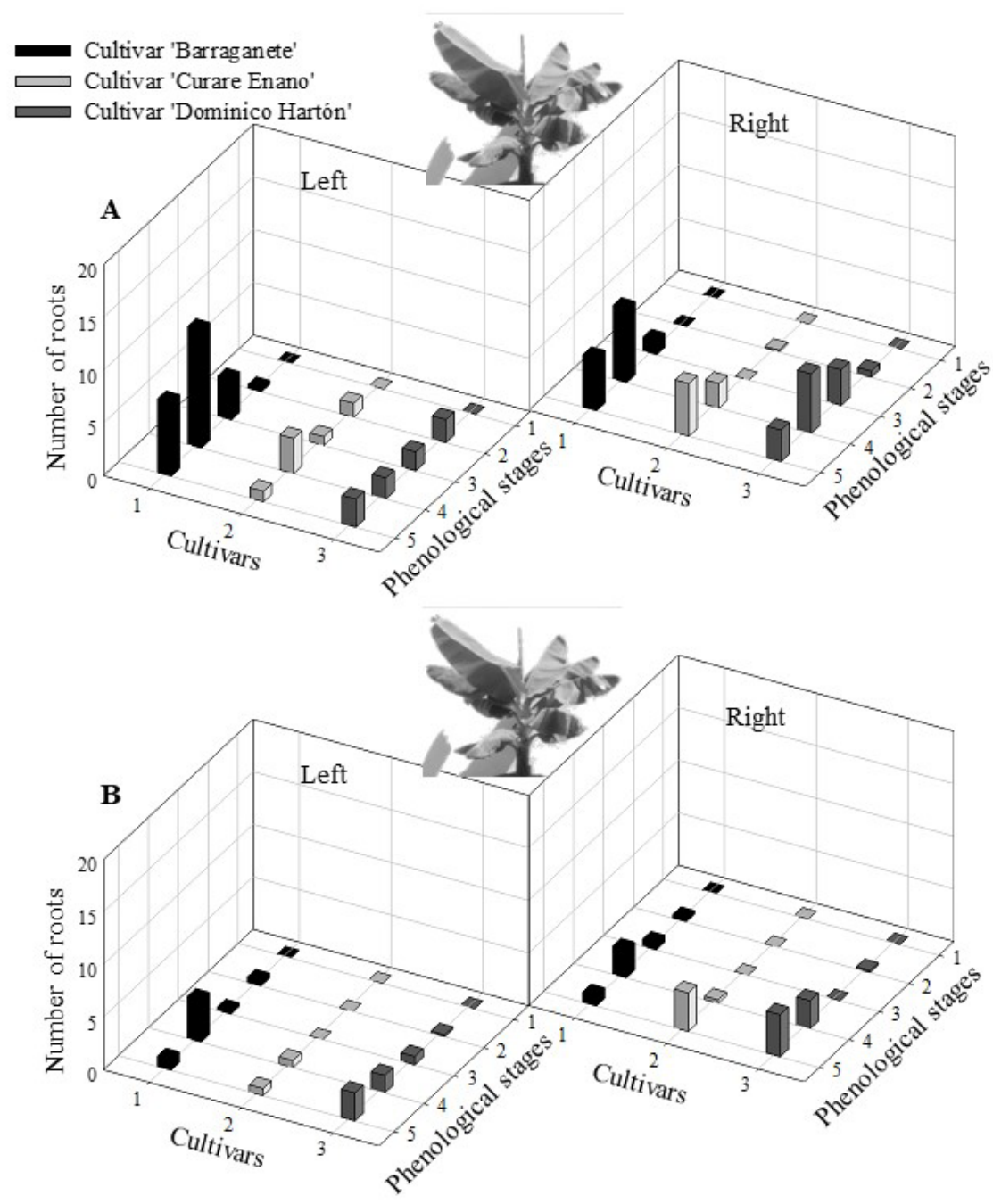

Figure 2. Map of the average root distribution of plantain cultivars, 1) 'Barraganete' (black bar), 2) 'Curare Enano' (light gray bar) and, 3) 'Dominico Hartón' (dark gray bar). A) $30 \mathrm{~cm}$ in length to the right and left, B) $40 \mathrm{~cm}$ in length to the right and left, and up to $60 \mathrm{~cm}$ in depth, in plants analyzed at the "Río Suma" Experimental Farm, "Laica Eloy Alfaro de Manabín" University, El Carmen, Ecuador. 

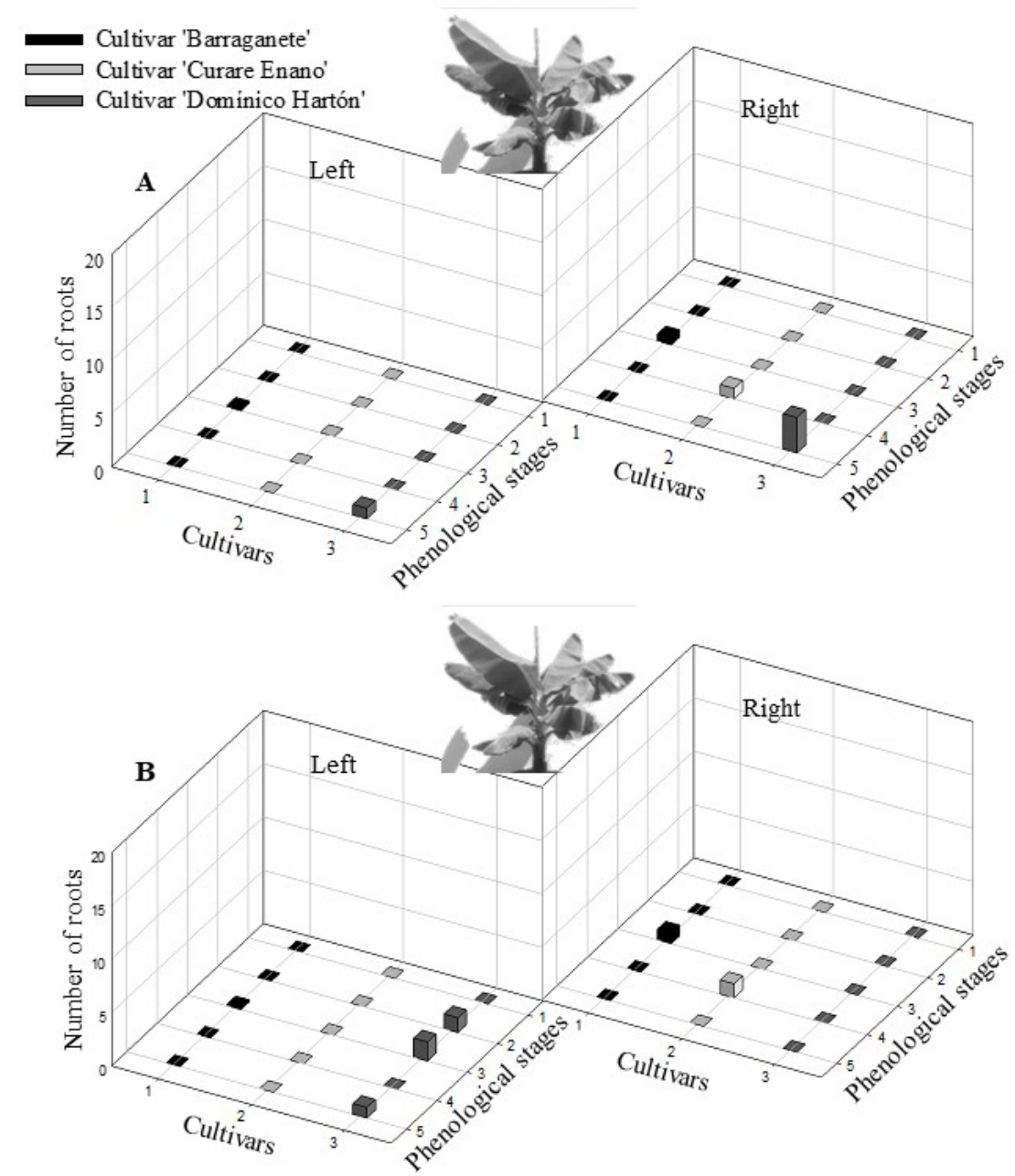

Figure 3. Map of the average root distribution of plantain cultivars, 1) 'Barraganete' (black bar), 2) 'Curare Enano' (light gray bar) and 3) 'Dominico Hartón' (dark gray bar). A) $50 \mathrm{~cm}$ in length to the right and left, B) $60 \mathrm{~cm}$ in length to the right and left, and up to $40 \mathrm{~cm}$ in depth in plants analyzed at the "Río Suma" Experimental Farm, "Laica Eloy Alfaro de Manabí” University, El Carmen, Ecuador.

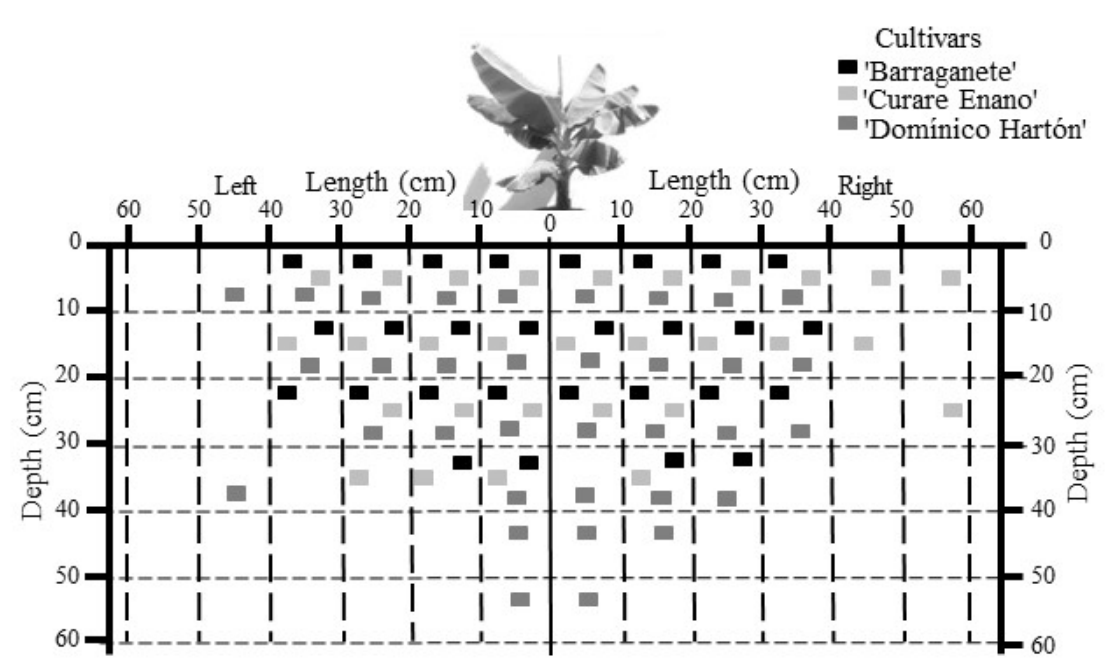

Figure 4. Map of the root distribution of 'Barraganete' (black bar), 'Curare Enano' (light gray bar) and 'Dominico Hartón' (dark gray bar) plantain cultivars up to $60 \mathrm{~cm}$ in length to the right and left and up to $40 \mathrm{~cm}$ in depth in plants analyzed at the "Río Suma" Experimental Farm, "Laica Eloy Alfaro de Manabí" University, El Carmen, Ecuador. 
Root growth and development in all directions form a three-dimensional structure that allows plants to explore the entire soil volume with greater or lesser intensity, as presented in the three plantain cultivars ('Barraganete', 'Curare Enano' and 'Dominico Hartón') evaluated in this investigation (Figures 1, 2, 3 and 4).

Barrera et al. (2011) pointed out that plantains have adventitious roots from their origin, fibrous or fasciculate, superficial, composed of primary, secondary and tertiary roots, which are distributed between 30 to $40 \mathrm{~cm}$ in depth, most of them concentrated in the first 15 at $20 \mathrm{~cm}$. These results coincided with those found in this research, where the greatest root volume was found in the first $20 \mathrm{~cm}$ of in depth and laterally between 40 to $60 \mathrm{~cm}$ ('Barraganete', 'Dominico Hartón' and 'Curare Enano', respectively). On the other hand, Barrera et al. (2011) also indicated that the length can reach 2.5 to $3 \mathrm{~m}$ in lateral growth and up to 1.5 $m$ in depth, depending on the soil characteristics. However, this result contrasts with the longitudinal and depth growth of those obtained in this research, where 'Barraganete', 'Dominico Hartón' and 'Curare Enano' cultivars reached 40, 50 and $60 \mathrm{~cm}$ laterally, respectively; as for depth, 'Barragante' and 'Curare Enano' cultivars reached $40 \mathrm{~cm}$ and 'Dominico Hartón' cultivar, $60 \mathrm{~cm}$ (Figure 4). The root penetration power of the three cultivars was weak, which suggests that the root distribution could be related to soil texture and structure.

Similar results were found by Fan et al. (2016) on root distribution in annual crops, indicating that an average of $61-76 \%$ of roots were found in the first $30 \mathrm{~cm}$ of soil, although with highly variable values. The estimated depth at which $50 \%$ of total roots were accumulated for different crops varied from 8 to $20 \mathrm{~cm}$. The horizontal root distribution was homogeneous across the soil profile and no root concentration was observed in rows.

In fact, Cabeza and Claasen (2017) highlighted that the physical soil characteristics, the depth of the water table, the origin of roots, the seed spacing and the type of crop cover affect root distribution, which is generally horizontal and superficial in plantain cultivation. This description coincided with that observed in this research.

It has also been observed that the root characteristics vary widely among plant species and these differences are due, in part, to adaptations to environmental conditions of plant habitats (ANDIVIA et al., 2019). On the other hand, species segregation along aridity and temperature gradients could be driven by differences in root architecture and growth (FRESCHET et al., 2017). The environmental conditions to which plants are exposed throughout their life cycle also affect root properties by altering root growth dynamics, morphology and architecture.
Regarding phenological stages, NRR was higher during stage IV (from leaf 31 to inflorescence emission with 31.78 roots $\cdot$ plant $\left.^{-1}\right)$, being statistically different $(\mathrm{P}<0.01)$ from stages I $\left(10.00\right.$ roots $\cdot$ plant $\left.^{-1}\right)$ and II $(20.22$ roots $\cdot$ plant $\left.^{-1}\right)$, without statistical differences $(\mathrm{P}>0.05)$ from stages III (23.97 roots $\cdot$ plant $\left.^{-1}\right)$ and V (20.67 roots $\cdot$ plant $\left.^{-1}\right)$ (Table 2; Figures 1, 2 and 3).

In the case of 'Barraganete' cultivar, horizontally covered $40 \mathrm{~cm}$ on both sides of the soil profile, representing $37.08 \%$ of total plant roots; of which 55.31 and $44.69 \%$ were distributed to the right and left sides of the plant, respectively. Of these, $93.74 \%$ occurred in the first $20 \mathrm{~cm}$ in depth and $6.26 \%$ between 30 and $40 \mathrm{~cm}$. Likewise, 'Curare Enano' cultivar presented horizontal roots between 40 and $60 \mathrm{~cm}$ in length. In the first $20 \mathrm{~cm}$ of depth $(96.50 \%)$, the remaining $3.50 \%$ reached up to $40 \mathrm{~cm}$ in depth; and in the case of 'Dominico Hartón' cultivar, horizontal root concentration was similar to that of 'Curare Enano' cultivar, with the presence of roots between 40 and $50 \mathrm{~cm}$ in the first $20 \mathrm{~cm}$ on both sides $(93.00 \%)$ and the remaining $7.00 \%$ reached up to the $60 \mathrm{~cm}$ in depth. At a greater soil depth $(60 \mathrm{~cm})$, root distribution was more heterogeneous, and 'Barraganete' and 'Curare Enano' cultivars developed roots that were up to $40 \mathrm{~cm}$, while 'Dominico Hartón' cultivar showed roots up to $60 \mathrm{~cm}$ (Figure 4).

TNR was statistically different $(\mathrm{P}<0.01)$ in stage IV $\left(58.22\right.$ roots plant $\left.{ }^{-1}\right)$ and stages I $\left(27.22\right.$ roots $\cdot$ plant $\left.^{-1}\right)$ and V (35.11 roots ' plant $\left.^{-1}\right)$ showed no differences $(\mathrm{P}>0.05)$ from stages II (40.84 roots $\cdot$ plant $\left.^{-1}\right)$ and III (44.24 roots $\cdot$ plant $\left.^{-1}\right)$. At the time of inflorescence emission (phenological stage IV), there was increase in the number of roots; therefore, TNR in this stage was 1.66 times higher than in stage $\mathrm{V}$ (Table 2).

Furthermore, regarding the cultivar interaction at phenological stage, it was found that the highest NRR and TNR occurred in 'Barraganete' cultivar in stage IV (44.00 and 78.33 roots $\cdot$ plant $^{-1}$ ), followed by 'Dominico Hartón' cultivar in stage III (31.40 and 53.40 roots plant $^{-1}$ ) and 'Curare Enano' cultivar in stage IV (23.00 and 47.00 roots plant $\left.^{-1}\right)$, respectively. However, it is important to note that in 'Dominico Hartón' cultivar, NRR and TNR in phenological stage IV (28.33 and 49.33 roots $\cdot$ plant $^{-1}$ ) compared to stage III was 1.11 and 1.08 times lower, respectively. All cultivars in phenological stage I presented the lowest NRR, without statistical differences among them. On the other hand, decrease in NRR was observed for all cultivars in stage $\mathrm{V}$, which coincided with the emission of roots in the successional offspring, before plants reached senescence (Figure 5). 
Ibáñez et al. (2000) indicated that there is antagonistic balance between roots and shoots; hence, when one of them grows, the other stops its growth. Fruit production also modifies root development, as observed in this research, where increase in the number of roots was observed as plants were forming their structure until reaching the flowering process. From this point, the growth of the root system is slowed down until reaching the harvest stage. Based on field findings, data not shown, the research team observed a decrease in leaf size as the inflorescence emission approaches (beginning of the flowering process).
Knowing the distribution and growth dynamics of the root system of different plantain cultivars associated with the phenological state is of great importance for the proper execution of agronomic practices, such as: location and dosage of fertilizers; supervision, damage quantification and control of rhizophagous pests, in order to obtain greater efficiency in treatments with fungicides and insecticides that occurs through root absorption.

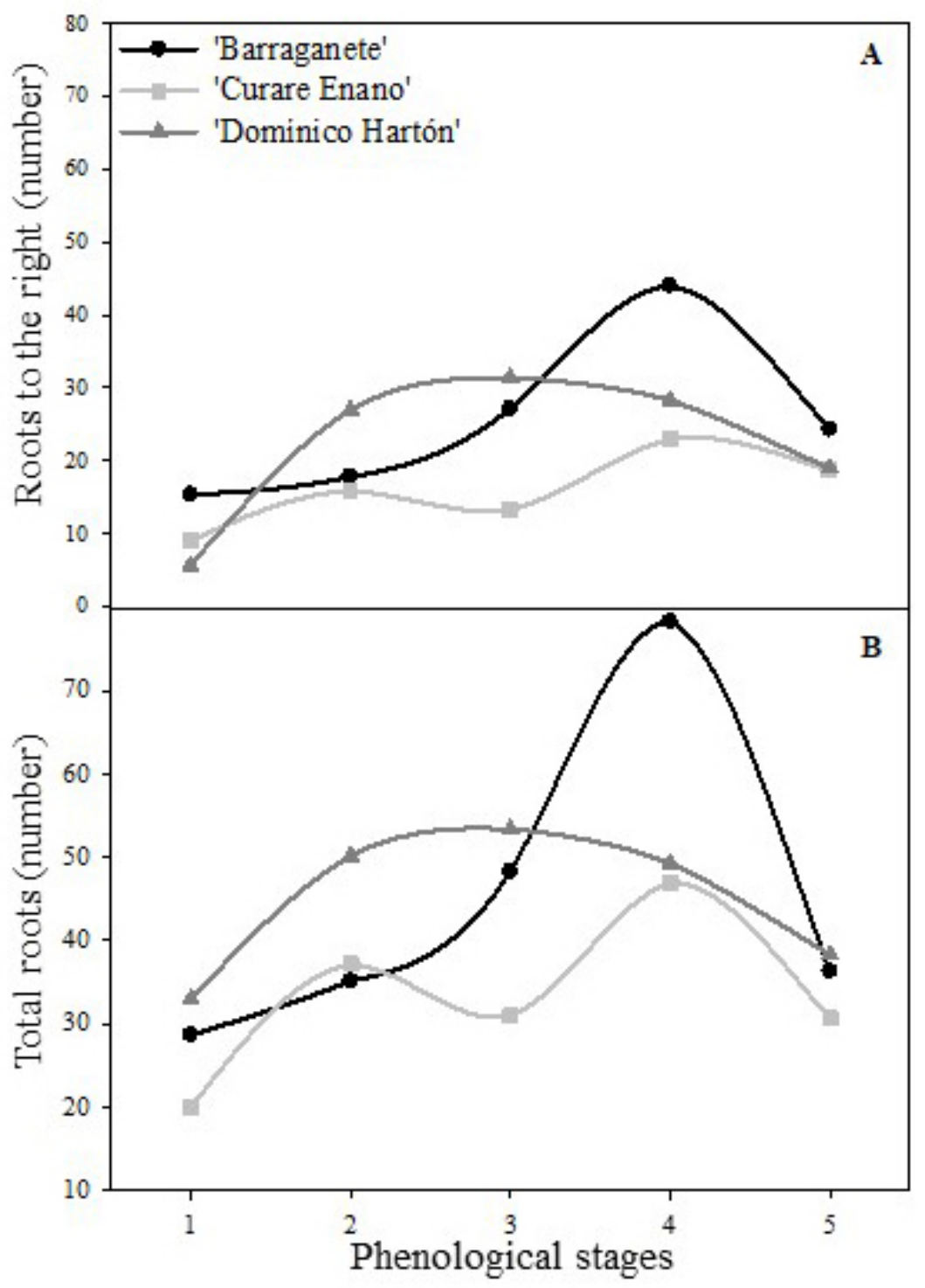

Figure 5. Interaction of plantain cultivars at phenological stages. A) Average number of roots to the right (NRR) and B) Total average number of roots of plants in plantain cultivars (Musa AAB) 'Barraganete' (black line), 'Curare Enano' (light gray line) and 'Dominico Hartón' (dark gray line), grown at the "Río Suma” Experimental Farm, "Laica Eloy Alfaro de Manabí" University, El Carmen, Ecuador. Phenological stages: 1) 10 leaves, 2) 20 leaves, 3) 30 leaves, 4) 40 leaves (inflorescence) and 5) harvest. 
At the same time, roots constitute the anchorage of plant shoots in the soil; in addition to fulfilling the function of absorbing water and nutrients dissolved in the soil solution, which are necessary for plant growth and development. Better crop management implies better use of nutrients and water, minimizing environmental impact, and knowing the quantity and distribution of roots in the soil profile. It is also important to know how the root system develops during the vegetative cycle, and how root development can be affected by the nutritional status of plants, as well as soil moisture and tillage intensity. This would lead to agronomic management that involves the optimal use of resources (soil, water, nutrients, among others; Figures 1, 2 and 3).

According to Belalcázar (2005) and Robinson and Galán (2012), the relative scarcity of tertiary roots, which produce most of root hairs, has been a factor that contributes to low productivity and consequently low yield.

\section{Conclusion}

The three plantain cultivars presented superficial root development, where the greatest amount was found in the first $20 \mathrm{~cm}$ in depth $(94.01 \%)$, and horizontally distributed between 40 to $60 \mathrm{~cm}, 5.21 \%$ of roots were located from 21 to $40 \mathrm{~cm}$ in depth and exploring the horizontal range of 30 and $50 \mathrm{~cm}$ while for $0.78 \%$, this range was between 41 and $60 \mathrm{~cm}$. On the other hand, it was observed that the root emission decreased with inflorescence and resumed in succession shoots, when the plant reaches senescence.

\section{References}

ANDIVIA, E.; ZUCCARINI, P.; GRAU, B.; DE HERRALDE, F.; VILLAR-SALVADOR, P.; SAVÉ, R. Rooting big and deep rapidly: the ecological roots of pine species distribution in southern Europe. Trees, Darmstadt, v.33, n.1, p.293-303, 2019.

ARISTIZÁBAL, M.; JARAMILLO, C. Identificación y descripción de las etapas de crecimiento del plátano Dominico Hartón (Musa AAB). Agronomía, Manizales, v.18, n.1, p.29-40, 2010.
AVELLÁN VÁSQUEZ, L.; COBEÑA LOOR, N.; ESTÉVEZ CHICA, S.; ZAMORA MACÍAS, P.; VIVAS CEDEÑO, V; GONZÁLEZ RAMÍREZ, I.; SÁNCHEZURDANETA, A.B. Exportación y eficiencia del uso de fósforo en plátano 'Barraganete' (Musa paradisiaca L.). Revista Fitotecnia Mexicana, Chapingo, v.43, n.1, p.2533, 2020.

BARRERA VIOLETH, J.L.; CARDONA AYALA, C.E.; CAYÓN SALINAS, D.G. El cultivo de plátano (Musa AAB Simmonds): ecofisiología y manejo cultural sostenible. Córdoba: Editorial Zenú, 2011. 102p.

BELALCÁZAR CARVAJAL, S.L. El cultivo del plátano en el Trópico. Bogotá: Instituto Colombiano Agropecuario, 2005. 376p.

CABEZA, R.A.; CLAASSEN, N. Sistemas radicales de cultivos: extensión, distribución y crecimiento. Agro Sur, Valdivia, v.45, n.2, p.31-45, 2017.

DÍAZ-ZORITA, M.; GRASSO, A. Fertilización intensificada de planteos agrícolas. Fertilizar, Buenos Aires, v.37, p.12-20, 2017.

DUQUE, L.O.; VILloRDON, A. Root branching and nutrient efficiency: status and way forward in root and tuber crops. Frontiers Plant Science, Lausanne, v.10, p.237, 2019.

FAN, J.; McCONKEY, B.; WANGA, H.; JANZEN, H. Root distribution by depth for temperate agricultural crops. Field Crops Research, Amsterdam, v.189, p.6874, 2016.

FIXEN, P.E. Eficiencia del uso de nutrientes en el contexto de agricultura sostenible. Informaciones Agronomicas, Quito, v.76, p.1-9, 2010.

FRESCHET, G.T.; VALVERDE-BARRANTES, O.J.; TUCKER, C.M.; CRAINE, J.M.; MCCORMACK, M.L.; VIOLLE, C.; et al. Climate, soil and plant functional types as drivers of global fine-root trait variation. Journal of Ecology, Oxford, v.105, n.5, p.1182-1196, 2017. 
GUERRERO, M. Guía técnica del cultivo plátano. El Salvador: Centro Nacional de Tecnología Agropecuaria y Forestal Enrique Alvarez Córdova, 2010, 24p. Disponível em: http://centa.gob.sv/ docs/guias/frutales/GUIA CULTIVO PLATANO2011.pdf. Acesso em: 25 fev. 2020.

IBÁÑEZ-MARTÍNEZ, A.; BECERRIL-ROMÁN, A.E.; CASTILLO-MORALES, A.; PARRA-QUEZADA, R.A.; LÓPEZ-CASTAÑEDA, C. Efecto de cubiertas, riego y fertilización foliar en el desarrollo radical del manzano. Terra, Chapingo, v.18, p.225-237, 2000.

INAMHI - Instituto Nacional de Meteorología e Hidrología. Anuario meteorológico 53-2013. Quito,

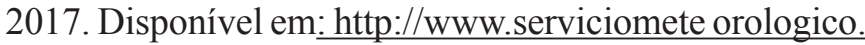
gob.ec/docum_institucion/anuarios/meteorologicos/ Am_2013.pdf. Acesso em: 22 fev. 2020.

INEC - Instituto Nacional de Estadísticas y Censos. Encuesta de superficie y producción agropecuaria continua (ESPAC) Contenidos. Quito. 2017. Disponível em: http://www.ecuadorencifras.gob.ec/documentos/ web-inec/Estadisticas_agropecuarias/espac/espac 2017/ Informe Ejec utivo ESPAC 2017.pdf. Acesso em: 01 mar. 2020.

OGURA, T.; GOESCHL, C.; FILIAULT, D.; MIREA, M.; SLOVAK, R.; WOLHRAB, B.; SATBHAI, S.B.; BUSCH, W. Root system depth in Arabidopsis is shaped by EXOCYST70A3 via the dynamic modulation of auxin transport. Cell, Cambridge, v.178, n.2, p.400-412. e16. 2019.
PAGÈS, L.; BÉCEL, C.; BOUKCIM, H.; MOREAU, D.; NGUYEN, C.; VOISIN, A.S. Calibration and evaluation of ArchiSimple, system a simple model of root architecture. Ecological Modeling, New York, v.290, p.76-84, 2013.

SÁNCHEZ-CALDERÓN, L.; IBARRA-CORTEZ, M.E.; ZEPEDA-JAZO, I. Root development and abiotic stress adaptation. In: VAHDATI K.; LESLIE C. (ed.). Abiotic stress - plant responses and applications in agriculture. Rijeka: InTech, 2013. p.135-168.

STATISTICAL ANALYSIS SYSTEM. SAS studio user's guide: statistics. Versión 15.1. Cary: SAS Institute, 2020. Disponível e: https://support.sas.com/ documentation/onlinedoc/stat/indexproc.html\#stat151. Acesso em: 05 jan. 2020.

VARGAS-CALVO, A.; ACUÑA-CHINCHILLA, P.; VALLE-RUIZ, H. La emisión foliar en plátano y su relación con la diferenciación floral. Agronomía Mesoamericana, San José, v.26, p. 119-128, 2015.

WAIDMANN, S.; RUIZ ROSQUETE, M.; SCHÖLLER, M.; SARKEL, E.; LINDNER, H.; LARUE, T.; PETŘÍK, I.; DÜNSER, K.; MARTOPAWIRO, S.; SASIDHARAN, R.; NOVAK, O.; WABNIK, K.; DINNENY, J.R.; KLEINE-VEHN, J. Cytokinin functions as an asymmetric and antigravitropic signal in lateral roots. Nature Communications, London, v.10, p.3540, 2019. 